\author{
Dr inż. Małgorzata BORKOWSKA-NISZCZOTA \\ Wydział Inżynierii Zarządzania, Politechnika Białostocka \\ e-mail: m.borkowska@pb.edu.pl \\ ORCID: 0000-0003-2169-6062
}

DOI: $10.15290 /$ oes.2019.03.97.08

\title{
POLITYKA OPARTA NA KLASTRACH W DOKUMENTACH STRATEGICZNYCH REGIONÓW POLSKI WSCHODNIEJ ${ }^{1}$
}

\begin{abstract}
Streszczenie
Cel - Celem niniejszego artykułu jest zidentyfikowanie na podstawie założeń dokumentów strategicznych województw Polski Wschodniej zainteresowania władz regionalnych klastrami, jako instrumentami rozwoju regionalnego, wdrażania innowacji i regionalnych specjalizacji oraz przewidzianego na ich rozwój wsparcia.

Metoda badań - Dla realizacji celu wykorzystano technikę desk research. Analizie poddano dokumenty strategiczne województw: podkarpackiego, podlaskiego, lubelskiego, warmińsko-mazurskiego, świętokrzyskiego, tj. strategie rozwoju regionalnego oraz regionalne strategie innowacji.

Wnioski - Z przeprowadzonej analizy wynika, że pomimo zainteresowania władz klastrami jako narzędziami aktywizującymi rozwój regionów, w większości dokumentów brakuje konkretnych rozwiązań prowadzenia polityki opartej o klastry.
\end{abstract}

Słowa kluczowe: klastry, dokumenty strategiczne, polityka oparta na klastrach, instrumenty wsparcia

\section{CLUSTER-BASED POLICY IN STRATEGIC DOCUMENTS OF EASTERN POLAND REGIONS}

\section{Summary}

Purpose - The purpose of this article is to identify, on the basis of the assumptions of strategic documents of the voivodships of Eastern Poland, the interest of regional authorities in clusters as instruments of regional development, implementation of innovations and regional specializations and support provided for their development.

Research method - The desk research technique was used for the realization of the objective. The strategic documents (i.e. regional development strategies and regional innovation strategies) from the following voivodeships: Podkarpackie, Podlaskie, Lubelskie, Warminsko-Mazurskie, Swiętokrzyskie were analysed.

1 Artykuł wpłynął 28 maja 2018 r., zaakceptowano 6 lutego 2019 r.

Article received 28 May 2018, accepted 6 February 2019.

Badania zrealizowane $\mathrm{w}$ ramach pracy $\mathrm{nr} \mathrm{S} / \mathrm{WZ} / 5 / 2015$, finansowane ze środków na naukę MNiSW. 
Results - The results of the analysis show that despite the interest of the authorities in clusters as tools for activating the development of the regions, most documents lack any defined policy solutions based on clusters.

Key words: clusters, strategic documents, cluster-based policy, support instruments

JEL classification: L14, O29, R58

\section{Wstęp}

W dokumencie Strategii „Europa 2020” za priorytety rozwoju Europy uznaje się rozwój inteligentny, czyli rozwój gospodarki opartej na wiedzy i innowacji, rozwój zrównoważony oraz sprzyjający włączeniu społecznemu [Komunikat Komisji..., 2010, s. 5]. Mogą być one osiagnięte przez gospodarki oparte na nowoczesnych i innowacyjnych inicjatywach klastrowych. Specyficzne struktury, określane jako klastry, przyczynić się moga także do podnoszenia regionalnej konkurencyjności i w konsekwencji do wysokiej dynamiki wzrostu. Pozytywny wpływ specyfiki klastra (polegającej na łączeniu potencjałów sektora biznesu, nauki i publicznego) na innowacyjność, produktywność i przedsiębiorczość przekłada się na wykształcenie lub utrzymanie przewagi konkurencyjnej danej lokalizacji [Kierunki i polityka rozwoju..., 2009, s. 7]. W związku z powyższym należy dążyć do rozwoju takich form kooperacji - zwłaszcza na obszarach o opóźnionym stopniu rozwoju, do których należy makroregion Polski Wschodniej.

W ścisłym związku z rozwojem gospodarki opartej na wiedzy i innowacji (inteligentnym wzrostem) pozostaje smart specialisation [Romanowska i in., 2014, s. 56]. Idea inteligentnej specjalizacji stanowi relatywnie nowy czynnik, który powinien być uwzględniany w dokumentach planowania działań wspierających rozwój innowacyjności, tworzonych na szczeblu regionalnym [Del Castillo i in., 2011]. Jest też odpowiedzia na poszukiwanie nowych zrównoważonych koncepcji wzrostu, skłania się ku identyfikacji własnych zasobów i wykorzystania ich mocnych stron w tworzeniu wyższej wartości dodanej [Ketels, 2013]. W koncepcji inteligentnej specjalizacji klastry postrzegane są jako podstawowy element identyfikacji obszarów priorytetowych. Zastosowanie klastrów do identyfikacji inteligentnych specjalizacji pozwala na uniknięcie powielania specjalizacji innych regionów [Ropęga, 2016, s. 97]. Na etapie wdrażania regionalnej strategii innowacji klastry powinny stać się skutecznymi platformami do realizacji celów inteligentnej specjalizacji [Foray i in., 2012, s. 71].

A. Klasik traktuje sektory kreatywne oraz ich klastry jako najistotniejsze czynniki kreujące kierunki rozwoju regionów [Rola sektora kultury..., 2010]. Ich rolą ma być sukcesywne przekształcanie gospodarki wiedzy w gospodarkę kreatywna, której kluczem do sukcesu biznesowego będzie posiadanie tzw. inteligencji kreatywnej, czyli umiejętności wykorzystania osób kreatywnych oraz zdolności komunikacyjnych dla tworzenia nowych wartości w społeczeństwach [Naussbaum, 2013].

Rozwój klastrów powinien być wpisany w politykę tworzoną na różnych szczeblach zarządzania, zwłaszcza regionalnym. Klastry mogą bowiem stanowić funda- 
ment rozwoju regionalnego. Pierwszymi instrumentami rozwoju regionalnego w Polsce były specjalne strefy ekonomiczne oraz roboty publiczne i prace interwencyjne. Istotną rolę odgrywały też strategie rozwoju oraz kontrakty wojewódzkie. Postępujący rozwój sprawił, że pojawily się nowe instrumenty, takie jak parki technologiczne, inkubatory przedsiębiorczości oraz klastry [Sanetra-Półgrabi, 2011, s. 102]. Znaczenie i popularność klastrów spowodowały, iż zaczęła rozwijać się koncepcja polityki rozwoju opartego na klastrach. Duża liczba krajów i samorząaów regionalnych sformułowała $i$ wdrożyła ten typ polityki. Ze względu na swój horyzontalny charakter polityka wspierania klastrów stanowi ważny element kilku dziedzin polityki gospodarczej: regionalnej, innowacyjnej czy przemysłowej [Figiel, Węgrzynek, 2013].

W artykule, w części pierwszej, w oparciu o analizę literatury przedmiotu, przedstawiono teoretyczne zagadnienia polityki opartej na klastrach, jej znaczenie oraz rolę klastrów dla rozwoju regionu. Studia literaturowe poprzedziły część drugą opracowania. Celem części drugiej i jednocześnie celem głównym artykułu jest zidentyfikowanie, na podstawie założeń dokumentów strategicznych województw Polski Wschodniej, zainteresowania władz regionalnych klastrami jako instrumentami rozwoju regionalnego, wdrażania innowacji i regionalnych specjalizacji oraz przewidzianego na ich rozwój wsparcia. Dla realizacji celu wykorzystano technikę badawczą desk research (analizę źródeł zastanych). Analizę przeprowadzono dla dokumentów będących pierwszym i drugim szczeblem programowania strategicznego (strategii rozwoju regionalnego oraz regionalnych strategii innowacji), opracowanych dla każdego z pięciu województw Polski Wschodniej: podkarpackiego, podlaskiego, lubelskiego, warmińsko-mazurskiego oraz świętokrzyskiego.

Badaniem objęto dokumenty województw Polski Wschodniej z uwagi na to, że jest to zwarty obszar o najniższym poziomie rozwoju gospodarczego w kraju i jeden z najsłabszych w Unii Europejskiej. Klastry w makroregionie mogą wygenerować szereg korzyści, które przyczynią się do zdynamizowania jego rozwoju.

\section{Istota klastrów i polityki klastrowej}

Funkcjonowanie klastrów, rozumianych jako ,geograficzne zjawisko wzajemnie powiązanych firm, wyspecjalizowanych dostawców, jednostek świadczących usługi, firm działających $\mathrm{w}$ pokrewnych sektorach $\mathrm{i}$ związanych $\mathrm{z}$ nimi instytucji (np. uniwersytetów, jednostek normalizacyjnych i stowarzyszeń branżowych) w poszczególnych dziedzinach, konkurujących między sobą, ale również współpracujących" [Porter, 2001, s. 246], może przynosić wiele korzyści nie tylko z perspektywy uczestników tego powiązania, ale także w szerszym kontekście - regionalnym. Na korzyści bezpośrednie dla regionu, m.in. rozwój kapitału ludzkiego i społecznego, budowanie zaufania i dialogu społecznego, przyspieszony rozwój infrastruktury społecznej, technicznej oraz infrastruktury otoczenia biznesu, przyciaganie inwestycji zagranicznych, tworzenie nowych przedsiębiorstw, budowanie marki regionu, wspieranie zasobów specyficznych regionu, wspieranie tworzenia i efektywności funkcjonowania regionalnych systemów innowacyjnych wskazuje J. Kaźmierski 
[2012, s. 106-107]. Klastry, jak twierdzą E. Skawińska i R. Zalewski [2009, s. 31], sa predysponowane do najbardziej sprawnego wdrażania koncepcji rozwoju zrównoważonego. Z uwagi na koncentrację przestrzenna, konkurencję i współpracę, rozwój umiejętności i kompetencji, elastyczną specjalizację można domniemywać, że zapewniaja one w większym stopniu spójność realizacji celów ekonomiczno-społecznych i ekologicznych niż formy rozproszone.

Biorąc pod uwagę korzyści z działalności klastrów, władze regionalne powinny mieć na uwadze ich rozwój, wykorzystując w tym celu odpowiednie instrumenty wsparcia. Działania wspomagające funkcjonowanie klastrów oraz ich rozwój powinny być odpowiednio zaplanowane [Kraska, 2012, s. 95]. Wspieranie rozwoju klastrów, szczególnie o największym potencjale konkurencyjnym i kluczowym znaczeniu dla gospodarki regionu, powinno być założeniem strategicznych dokumentów programowych regionu (strategii rozwoju, regionalnych strategii innowacji). Polityka wspierania klastrów dla kluczowych obszarów powinna być zatem wdrażana $\mathrm{w}$ ramach polityki regionalnej. Wsparcie klastrów, które powstaja we wszystkich sektorach gospodarki (chociaż dominują w sektorach wysokotechnologicznych) musi znaleźć też oparcie w polityce innowacyjnej. Dla klastrów, niezależnie od typu zaawansowana technologicznego, ważne są zalety z funkcjonowania w ramach sieci, takie jak: ułatwienie komunikacji, możliwość organizacji wspólnych przedsięwzięć (w tym o charakterze innowacyjnym) oraz efekt synergii [Gurba, 2012, s. 81]. Polityka wspierania klastrów może być też umiejscowiona jako agenda polityki naukowo-technologicznej, przemysłowej lub mieć charakter horyzontalny (kiedy jej filozofia i elementy znajdują się w każdej ze wspomnianych polityk [Brodzicki i in., 2004, s. 18]. Sektor publiczny powinien prowadzić taką politykę, która nie będzie szkodliwa dla rozwoju klastrów, firm w nim działających oraz całego obszaru [Lisowska, Rubisz, 2011, s. 52].

W literaturze spotyka się pojęcia - polityka rozwoju oparta na klastrach oraz polityka klastrowa. Polityka oparta na klastrach (CBP - Cluster-Based Policy) to zespół działań i instrumentów wykorzystywanych przez władze różnych szczebli dla podnoszenia poziomu konkurencyjności gospodarki poprzez stymulowanie rozwoju istniejących bądź tworzenie nowych systemów klastrowych przede wszystkim na szczeblu regionalnym [Brodzicki i in., 2004, s. 16]. Wyróżniają ją następujące elementy [Brodzicki i in., 2004, s. 16]: rynek jest jej siłą napędową, łączy różnorodne podmioty, opiera się na wspólpracy i wspólnych działaniach, posiada strategiczny charakter - pomaga w kształtowaniu wspólnej wizji, kreuje nową wartość.

Polityka rozwoju oparta na klastrach (posiada szersze znaczenie od polityki klastrowej) zawiera w sobie założenia polityki klastrowej i wpływa na tworzenie podstawowych warunków do powstawania klastrów, jednocześnie wykorzystuje ona strukturę klastra jako narzędzie do procesu poprawy konkurencyjności całego systemu gospodarczego, w którym został on zlokalizowany. Z kolei za politykę klastrową uważa się wszystkie działania podejmowane przez władze samorządowe, samodzielnie lub wspólnie z firmami, uniwersytetami i innymi podmiotami, które są skierowane do klastrów w celu wzrostu ich poziomu konkurencyjności [Ketels, 2009, s. 19; Kraska, 2013, s. 42] z wyłączeniem działań podejmowanych przez inne 
podmioty działające samodzielnie, np. oddolne inicjatywy klastrowe lub działania władz nie skierowane do klastrów (ale mogące na nie wpływać) i nie skupiające się na wzroście konkurencyjności klastra (ale mogące ich używać do tworzenia instytucji, które przyniosą korzyści dla całego regionu) [Plawgo, 2010].

Przez węższy zakres polityki klastrowej M. Dzierżanowski [2006] rozumie wspieranie koordynatorów klastra, których funkcjonowanie przyczynia się do rozwoju danego skupiska podmiotów gospodarczych i instytucji otoczenia. W szerszym zakresie z kolei obejmuje wiele polityk i instrumentów, które w sposób skoordynowany wspierają rozwój klastrów.

Jak twierdzi M. Klimczuk-Kochańska [2012, s. 156] wspólne wysiłki na rzecz wzmocnienia tworzonych struktur klastrów moga przyjmować rolę swego rodzaju „polityki” rozwoju klastrów rozumianej jako wspólne działania przedsiębiorstw, władz różnych szczebli i instytucji otoczenia biznesu dla osiągnięcia łączących ich celów, którymi mogą być korzyści wynikające z rozwoju klastrów gospodarczych. Realizacja polityki rozwoju klastrów ma dwojaki charakter. Może polegać na oddolnym wspieraniu podmiotów $\mathrm{i}$ instytucji lub na odgórnych działaniach podejmowanych przez władze publiczne. W praktyce zazwyczaj występują, z różnym nasileniem, oba podejścia jednocześnie.

W Europie brak jednolitego modelu polityki rozwoju klastrów. Wyróżnia się kraje, które prowadza politykę na poziomie narodowym, na poziomie regionalnym, w których tworzone są narodowe ramy dla realizacji polityki regionalnej oraz kraje, które nie realizuja polityki specyficznej w odniesieniu do klastrów [European Trend Chart, 2003, s. 11]. Raport dla holenderskiego Ministerstwa Gospodarki wskazywał na cztery modele CBP (Cluster-Based Policy) nastawione na: kreowanie przewagi konkurencyjnej w zakresie kluczowych sektorów gospodarki lub strategicznych łańcuchów wartości dodanej, podnoszenie konkurencyjności sektora MSP, stymulowanie rozwoju regionalnego, intensyfikację współpracy przemysłu ze sferą badań [Boekholt, Thuriaux, 1999]. W praktyce gospodarczej wdrażany jest najczęściej policy-mix, który $\mathrm{z}$ reguły obejmuje wszystkie wymienione powyżej obszary jednocześnie [Kierunki i polityka rozwoju..., 2009, s. 16].

W tabeli 1 wyszczególniono, zaproponowane przez S.A. Rosenfelda [2002], siedem grup ogólnych kierunków działań na rzecz rozwoju gron, w kontekście warunków regionów charakteryzujących się niskim poziomem rozwoju.

Wśród najczęściej stosowanych instrumentów polityki rozwoju klastrów w UE znajdują się: usprawnienie obiegu informacji, tworzenie platform wspólpracy firm i instytucji naukowo-badawczych, wspieranie wspólnego marketingu i kampanii eksportowych, dofinansowanie konsultingu i szkoleń z zakresu nowych metod organizacji procesów technologicznych [Klimczuk-Kochańska, 2012, s. 160].

Za główny cel CBP (Cluster-Based Policy) obiera wzrost konkurencyjności gospodarki regionalnej i narodowej, poprzez stymulowanie współpracy między przedsiębiorstwami w kierunku tworzenia innowacyjnych rozwiązań oraz wzmacnianie pozycji już istniejących klastrów dzięki wyznaczaniu kierunków rozwoju, wzrostowi specjalizacji tworzących je firm $\mathrm{i}$ instytucji, co sprzyja z kolei powstawaniu efektu synergii. Efektywna i z konsekwencją wdrażana polityka oparta 
o klastry może prowadzić do przekształcenia się klastrów w regionalne systemy innowacyjne o efektywnej absorpcji, innowacjach procesowych, produktowych i organizacyjnych [Brodzicki, Szultka, 2002, s. 51]. Realizacja powyższego celu może zależeć od zakresu i skali interwencji władz publicznych oraz wykorzystywanych instrumentów wsparcia.

\section{TABELA 1}

\section{Działania na rzecz rozwoju gron wg S.A. Rosenfelda}

\begin{tabular}{|c|c|}
\hline $\begin{array}{l}\text { Ogólne kierunki } \\
\text { działań }\end{array}$ & Działania \\
\hline $\begin{array}{l}\text { Działania zmierzające } \\
\text { do poznania i bench- } \\
\text { markingu gospodarki } \\
\text { regionu }\end{array}$ & $\begin{array}{l}\text { identyfikacja klastrów, modelowanie i tworzenie mapy } \\
\text { systemowych relacji, benchmarking w stosunku do konkurentów }\end{array}$ \\
\hline $\begin{array}{l}\text { Działania na rzecz } \\
\text { zaangażowania }\end{array}$ & $\begin{array}{l}\text { rozpoznanie stowarzyszeń w obrębie klastrów lub ich tworzenie, } \\
\text { formalizacja kanałów komunikacyjnych, sprzyjanie rozwojowi } \\
\text { kooperacji pomiędzy firmami }\end{array}$ \\
\hline $\begin{array}{l}\text { Działania na rzecz } \\
\text { organizowania } \\
\text { i dostarczania usług }\end{array}$ & $\begin{array}{l}\text { organizowanie i rozprzestrzenianie informacji w klastrach, } \\
\text { stworzenie one-stop cluster hubs/centers - instytucjonalnego ośrodka } \\
\text { klastra, stworzenie zespołu przedstawicieli różnych organizacji } \\
\text { działających w klastrze, stworzenie w strukturach władz } \\
\text { wydziałów/departamentów zajmujących się klastrem, ułatwianie } \\
\text { relacji uczestników klastra z podmiotami zewnętrznymi }\end{array}$ \\
\hline $\begin{array}{l}\text { Działania na rzecz } \\
\text { kształtowania wyspecja- } \\
\text { lizowanych zasobów } \\
\text { pracy }\end{array}$ & $\begin{array}{l}\text { przygotowywanie kadr do wymogów zatrudnienia, wykorzysty- } \\
\text { wanie klastra jako kontekstu kształcenia kadr, założenie centrum } \\
\text { edukacyjnego na potrzeby klastra, kształtowanie partnerstwa } \\
\text { pomiędzy instytucjami edukacyjnymi a klastrem, wspieranie } \\
\text { regionalnych porozumień firm na rzecz podnoszenia kwalifikacji } \\
\text { kadry, tworzenie ponadregionalnych porozumień instytucji } \\
\text { edukacyjnych }\end{array}$ \\
\hline $\begin{array}{l}\text { Działania stymulujące } \\
\text { innowacyjność i przed- } \\
\text { siębiorczość }\end{array}$ & $\begin{array}{l}\text { inwestowanie w innowacje, wspieranie opartych na klastrze } \\
\text { inkubatorów przedsiębiorczości, zachęcanie do tworzenia sieci } \\
\text { wspierania przedsiębiorczości i uczenia się, wspieranie sieci } \\
\text { innowacyjnych, stworzenie, opartego na klastrze, centrum } \\
\text { technologicznego }\end{array}$ \\
\hline $\begin{array}{l}\text { Działania na rzecz } \\
\text { marketingu regionu }\end{array}$ & $\begin{array}{l}\text { tworzenie zachęt do inwestowania, promocja klastra, tworzenie } \\
\text { sieci eksportowych, wsparcie wykorzystania regionu jako wyróż- } \\
\text { niającej marki produktów klastra }\end{array}$ \\
\hline $\begin{array}{l}\text { Działania na rzecz } \\
\text { alokacji zasobów } \\
\text { i inwestycji }\end{array}$ & $\begin{array}{l}\text { stosowanie zachęt dla firm, priorytetowo traktujące grupy } \\
\text { i skupiska firm, inwestowanie w działalność B+R klastrów, } \\
\text { kształtowanie korzystnych warunków lokalizacyjnych }\end{array}$ \\
\hline
\end{tabular}

Źródło: [Rosenfeld, 2002, s. 15].

Właściwym poziomem realizacji polityki opartej o klastry w polskim układzie systemowym wydaje się być szczebel wojewódzki, ponieważ na tym poziomie 
zapadają decyzje kluczowe dla regionów. Strategie rozwoju regionalnego oraz regionalne strategie innowacji powinny w sposób bezpośredni adresować potrzeby zidentyfikowanych lub potencjalnych klastrów o dużym znaczeniu dla gospodarki oraz proponować konkretne rozwiązania [Brodzicki i in., 2004, s. 36]. Na szczeblu regionalnym istotnym narzędziem realizacji założeń i celów strategii będą Regionalne Programy Operacyjne. Dotychczas wsparcie w ramach tych programów było przeznaczone dla koordynatorów klastrów, którzy prowadzili działania na rzecz członków klastra. W okresie 2014-2020 forma ta została utrzymana, a dodatkową metoda jest bezpośrednie wsparcie firm i instytucji, będących członkami klastra, dla realizacji ich celów [Bucka, 2017, s. 69].

Intensywność powstawania klastrów można postrzegać jako następstwo prowadzonej polityki rozwoju klastrów. W Raporcie z inwentaryzacji klastrów w Polsce z 2015 r. wynika, iż liczba klastrów powstałych w latach 2003-2015, według regionów Polski Wschodniej, była następująca: w podkarpackim - 12, podlaskim - 8, świętokrzyskim - 4, warmińsko-mazurskim - 2, lubelskim - 11 [Buczyńska i in., 2016]. Analizę liczebności klastrów przeprowadził S. Olko [2015, s. 114]. Obejmowała całkowitą liczbę klastrów, które powstały od początku prowadzenia analiz (około 2006 r.). Obejmowała ona również klastry nieaktywne, stąd wielkości liczbowe nieco odbiegają od podanych w Raporcie. Według autora, liczba klastrów wynosiła w województwach: podkarpackim - 44, podlaskim - 38, świętokrzyskim 34, warmińsko-mazurskim - 28 i lubelskim - 48. Zdaniem B. Szymoniuk [2014, s. 220] zmienna i niespójna polityka klastrowa, połączona z przerostem administracji, komplikowała i wydłużała proces dofinansowania projektów oraz tworzyła nieuzasadnione bariery rozwoju, doprowadzające w konsekwencji do rozpadu większości powstałych inicjatyw klastrowych.

Władze regionalne powinny opracować zasady wspierania klastrów, które określą nie tylko sposoby wsparcia, ale i kryteria dostępu do nich. Zapewniło by to równy dostęp do środków publicznych oraz ukierunkowało aktywność klastrów na działania zgodne $\mathrm{z}$ prowadzona polityką regionalną. Ważne jest zaangażowanie klastrów w opracowywanie wytycznych regionalnej polityki klastrowej. Władze powinny także traktować klastry jako partnera w procesie wyznaczania inteligentnych specjalizacji i wdrażania regionalnych strategii innowacji [Plawgo, 2014, s. 191]. Władze publiczne mogą wspierać klastry stosując metody bezpośrednie w postaci bezpośredniej ingerencji, np. znaczny wpływ na zarządzanie klastrem lub wsparcie finansowe, albo też metody pośredniego oddziaływania w postaci działań związanych z promocja, marketingiem czy raportowaniem [Innovation Clusters..., 2007, s. 17].

W ramach prowadzonej polityki rozwoju klastrów inaczej powinno się traktować klastry duże, reprezentujące branże nastawione na rynki zewnętrzne, a inaczej małe, obsługujące rynki lokalne (regionalne). Instrumenty wsparcia powinny uwzględniać specyfikę klastrów i być dostosowane do stopnia ich rozwoju. Dla obu tych grup należy przewidywać różne formy i intensywność wsparcia [Innovation Clusters..., 2007, s. 188]. Wspieranie inicjatyw klastrowych przez władze - w tym animatorów klastra i instytucji organizujących współpracę, jest jednym z elementów tej polityki [Kierunki ipolityka rozpoju..., 2009, s. 15]. 
Władze publiczne, angażując się w rozwój klastrów za pomocą odpowiedniej polityki oraz wyboru właściwych narzędzi jej realizacji, muszą wystrzegać się popełniania błędów polegających na promowaniu klastrów wysokich technologii (gdy w danym regionie nie ma warunków do odniesienia sukcesu) i unikaniu poparcia dla rozwoju klastrów zajmujących się usługami (np. turystycznymi), które mogą mieć podstawowe znaczenie dla zrównoważonego rozwoju regionów [Pilarska, 2010, s. 99].

\section{Założenia dokumentów programowych władz regionalnych Polski Wschodniej w obszarze rozwoju współpracy klastrowej oraz instrumentów wsparcia}

\subsection{Założenia dla województwa podkarpackiego}

W województwie podkarpackim zrozumiano współczesne wyzwania i mechanizmy gospodarki opartej na innowacyjnym wzroście, stąd istnieje zainteresowanie klastrami jako jednymi z podstawowych narzędzi aktywizujących tego rodzaju rozwój. Nawiązywaniu aktywnej współpracy biznesowo-naukowej sprzyja klimat, który jest rezultatem polityki rozwoju regionalnego, realizowanej na poziomie zarówno wojewódzkim, jak i lokalnym [Wierżyński, 2012].

Klastering jako instrument podnoszenia konkurencyjności regionalnej gospodarki jest dostrzegany i uwzględniany w strategicznych dokumentach.

W dokumencie Strategia rozwoju województwa - Podkarpackie 2020 [2013] jeden z wniosków z diagnozy mówi o powstawaniu klastrów branżowych oraz wysokim poziomie współpracy przedsiębiorstw w zakresie innowacyjności. Jednocześnie wskazuje się na konieczność wspierania tego typu sieciowania podmiotów gospodarczych. W opracowanej wizji rozwoju województwa przyjmuje się, iż w 2020 r. wzrost atrakcyjności turystycznej regionu oraz konkurencyjność produktu turystycznego wesprą wielofunkcyjny rozwój obszarów wiejskich. Realnymi motorami wzrostu gospodarczego regionu w tym czasie staną się działające i nowo powstające klastry gospodarcze, grupy producenckie oraz struktury o charakterze międzysektorowym.

Jedną z dziedzin działań strategicznych, które pozwolą osiąnnąć cel główny „efektywne wykorzystanie zasobów wewnętrznych i zewnętrznych dla zrównoważonego i inteligentnego rozwoju społeczno-gospodarczego droga do poprawy jakości życia mieszkańców” jest „konkurencyjna i innowacyjna gospodarka” [Strategia rozwoju województwa - Podkarpackie, 2013, s. 30-31]. Celem tej dziedziny jest przemysł nowoczesnych technologii, wzmacniający konkurencyjność regionalnej gospodarki, a kierunkiem działania, wspieranie rozwoju klastrów oraz inicjatyw klastrowych. Wskazuje się na potrzebę wsparcia instytucjonalnego i finansowego, jakie winno być kierowane do już działających klastrów, skupiających w głównej mierze przedsiębiorców z sektorów kluczowych dla rozwoju województwa. Efektem realizowanych działań ma być [Strategia rozwoju województwa - Podkarpackie, 2013, s. 33]: 
- wzrost współpracy branżowej przedsiębiorstw,

- $\quad$ wzmocnienie i wzrost liczby klastrów na terenie województwa; w roku 2020 ma nastapić co najmniej podwojenie liczby klastrów w stosunku do roku 2012, kiedy to ich liczba wynosiła 19,

- $\quad$ wzrost współpracy pomiędzy klastrami i inicjatywami klastrowymi a sferą nauki,

- internacjonalizacja klastrów i inicjatyw klastrowych,

- rozwój ekonomiczny przedsiębiorstw zrzeszonych w klastrach,

- wzrost jakości kapitału ludzkiego w przedsiębiorstwach - członkach klastrów.

Innym celem dziedziny „konkurencyjna i innowacyjna gospodarka” jest budowa konkurencyjnej, atrakcyjnej oferty rynkowej, opartej na znacznym potencjale turystycznym regionu. Jednym z kierunków działań jest rozwój promocji turystycznej oraz partnerstwa służącego turystyce przyjazdowej do województwa. Wobec wzrostu konkurencji rynkowej pomiędzy destynacjami turystycznymi jest konieczny rozwój współpracy i współdziałania pomiędzy podmiotami, których działalność wpływa bezpośrednio lub pośrednio na przyjazdy do województwa. Proces ten obejmie podmioty gospodarki turystycznej, jednostki samorządu terytorialnego, organizacje pozarządowe i inne podmioty w województwie, a także spoza regionu. Jednym z zakładanych efektów realizowanych działań w tym zakresie ma być rozwój istniejących i tworzenie nowych klastrów oraz innych form organizacyjnych w ramach współpracy i współdziałania podmiotów sektora turystycznego i okołoturystycznego. Liczba podmiotów zrzeszonych w klastrach turystycznych, Podkarpackiej Regionalnej Organizacji Turystycznej oraz Lokalnych Organizacjach Turystycznych ma wynieść 500 w 2020 r. W 2012 r. wartość wskaźnika wynosiła 231 [Strategia rozwoju wojewódz̨twa - Podkarpackie, 2013, s. 28-39].

Wspieranie klasteringu zostało wpisane na listę priorytetowych zadań także w Regionalnej Strategii Innowacyjnej Województwa Podkarpackiego na lata 2014-2020. We wskazanym dokumencie, klastry zostały zaliczone do instrumentów wspierających o horyzontalnym i funkcjonalnym znaczeniu dla rozwoju inteligentnych specjalizacji, które wymagają wsparcia [Woźniak i in., 2015, s. 33-52].

Klastering dla władz regionu jest na tyle istotnym zagadnieniem, że stał się on przedmiotem odrębnego opracowania Kierunki rožwoju Wojewód乏twa Podkarpackiego w oparciu o klastry [Maj, Rychlicki, 2011]. Opracowanie prezentuje w sposób kompleksowy politykę klastrową regionu ukazując jej cztery zasadnicze obszary/wymiary [Wierżyński, 2012]:

- $\quad$ system wsparcia klastrów - system instytucji otoczenia biznesu, system wsparcia klastrów przez JST, określenie branż tzw. „wysokiej szansy”, regionalna platforma wymiany wiedzy i doświadczeń między klastrami,

- system edukacji i informacji w zakresie klasteringu - aktywizacja platformy informacyjnej o klastrach, system szkoleniowo-doradczy wspierający ich działanie,

- stworzenie dogodnych dla rozwoju klastrów warunków inwestycyjnych - system wsparcia finansowego klastrów, stworzenie atrakcyjnych warunków ekonomicz- 
nych (np. w postaci preferencji podatkowych) dla branż „wysokiej szansy”, zachęcanie funduszy pożyczkowych do finansowego angażowania się w inicjatywy klastrowe, utworzenie jednostek wspierających inkubację klastrów,

- $\quad$ system promocji klastrów - organizacja imprez targowych wspierających działalność klastrów, organizacja kampanii promujących ideę klasteringu, wsparcie klastrów w zakresie promocji ponadregionalnej i międzynarodowej.

Tego rodzaju dokumenty w całości poświęcone polityce klastrowej, opracowywane na poziomie zarządu województwa są w Polsce ciagle rzadkością.

\subsection{Założenia dla województwa podlaskiego}

Pierwszym dokumentem odnoszącym się do problemu współpracy sieciowej w województwie podlaskim jest Strategia Rozwoju Wojewódz̨twa Podlaskiego do roku 2020 [2013]. Przyjęte cele strategiczne zakładają równoległe prowadzenie działań na trzech kierunkach tak, aby zapewnić odpowiednio: wzrost przedsiębiorczości i konkurencyjności gospodarki, rozwój krajowych i międzynarodowych powiązań społeczno-gospodarczych regionu i wzrost jakości życia mieszkańców. U podstaw konstrukcji zakresu celów strategicznych leżą założenia o charakterze przekrojowym. Są to m.in. inteligentna specjalizacja oraz współpraca (strategia przyczyni się do powstawania w regionie kultury współpracy opartej na zaufaniu różnorodnych podmiotów i instytucji).

W strategii jako jeden z celów operacyjnych do celu strategicznego - konkurencyjna gospodarka przewidziano wzrost innowacyjności podlaskich przedsiębiorstw. Dla zapewnienia tego wzrostu, na bazie kluczowych branż regionu, w których działaja innowacyjne przedsiębiorstwa, powinny być tworzone platformy współpracy środowiska naukowego, instytucji otoczenia biznesu oraz sektora przedsiębiorstw [Strategia Rozwoju Województwa Podlaskiego..., 2013, s. 40].

W strategii podkreślono, że we współczesnej gospodarce, ale i w sferze społecznej, niezbędna jest umiejętność działania w strukturach sieciowych. Pojedyncze przedsiębiorstwa, instytucje nie są już w stanie samodzielnie sprostać stojącym przed nimi wyzwaniom. Muszą nauczyć się działać wspólnie w dynamicznych układach sieciowych. W strategii przewidziano, dla realizacji celu strategicznego - konkurencyjna gospodarka, budowę kapitału społecznego. Istotne jest wzmacnianie społecznych i obywatelskich kompetencji mieszkańców regionu oraz wspieranie dialogu społecznego. Nie bez znaczenia jest także kształtowanie kompetencji sprzyjających kooperacji, takich jak: tolerancja, otwartość, innowacyjność i kreatywność. Województwo podlaskie zamierza wykorzystać też szanse wynikające z możliwości pogłębienia współpracy z innymi regionami Polski, zwłaszcza jej wschodniej części, posiadającymi wspólne problemy i potencjały rozwoju [Strategia Rozwoju Województwa Podlaskiego..., 2013, s. 37-45].

W celu efektywnego wspomożenia wdrażania strategii w obszarze innowacyjności, badań i rozwoju oraz przedsiębiorczości został opracowany Plan rozwoju przedsiębiorczości w oparciu o inteligentne specjalizacje województwa podlaskiego na lata 2015 2020+(RIS3) [2016]. Celem nadrzędnym planu jest wzrost aktywności innowacyjnej 
oraz zwiększenie liczby przedsiębiorstw w regionie, który ma być realizowany w oparciu o trzy cele szczegółowe: konkurencyjność przez innowacje, przedsiębiorczość w powiązaniu z innowacyjnościa, kapitał ludzki dla innowacji. Dla ich realizacji założono różnorodne aktywności głównych aktorów regionalnego systemu innowacyjności (instytucje wiedzy, przedsiębiorcy, administracja, organizacje pozarządowe), oparte na konsolidacji wysiłków na rzecz rozwoju innowacyjności i przedsiębiorczości w regionie, a także efektywnej współpracy w ramach poczwórnej helisy. Planowane działania, mające na celu wzrost przedsiębiorczości, to m.in. promowanie procesów sieciowania przedsiębiorstw (w tym rozwoju inicjatyw klastrowych) oraz wspieranie tworzenia inicjatyw sieciowych w obszarze rdzenia specjalizacji [Plan rozwoju præedsiebiorczości..., 2016, s. 29-35].

\subsection{Założenia dla województwa lubelskiego}

W województwie lubelskim podstawowym dokumentem wskazującym na potrzebę współpracy klastrowej jest Regionalna Strategia Innowacii Wojewódžtwa Lubelskiego do 2020 roku [2014]. Zgodnie z jego założeniami województwo ma być regionem efektywnie wykorzystującym swój potencjał wewnętrzny, tworzacym produkty i usługi o wysokiej wartości dodanej, otwartym na innowacje i wspólpracującym oraz lepiej powiązanym gospodarczo i naukowo ze światem zewnętrznym. Realizacji wizji podporządkowane są cele szczegółowe, dotyczące m.in. wzmocnienia regionalnego systemu badań i innowacji oraz oparcie go na poczwórnej helisie spinającej wszystkich interesariuszy zainteresowanych współpraca; włączenia regionu w krajowy, jak również międzynarodowy łańcuch innowacji i sieci współpracy. Tym i innym założonym celom szczegółowym służą trzy priorytety.

Dla pierwszego priorytetu ,zwiększenie zdolności podmiotów gospodarczych do tworzenia i absorpcji wiedzy oraz wdrażania innowacji, zwłaszcza w regionalnych obszarach inteligentnej specjalizacji" [Regionalna Strategia Innowacji..., 2014, s. 41, 44] jednym z kierunków interwencji jest pobudzanie i rozwój współpracy sieciowej podmiotów gospodarczych (zrzeszeń branżowych, struktur wielobranżowych, zwłaszcza klastrów i platform współpracy angażujących sektor naukowo-badawczy). W ramach tego kierunku przewiduje się uruchomienie:

- pilotażowego programu „Partnerstwa, sieci i klastry”,

- zintegrowanego projektu wspierającego powstawanie nowych inicjatyw sieciowych/klastrowych, zwłaszcza tych nastawionych na rozwój współpracy międzyregionalnej, ponadregionalnej i międzynarodowej,

- $\quad$ autonomicznych instrumentów wspierających rozwój już działających struktur sieciowych i klastrowych,

- autonomicznych instrumentów dedykowanych profesjonalizacji integratorów sieci/klastrów (kadr/organizacji zarządzających sieciami/klastrami),

- autonomicznych instrumentów służących wypracowaniu dla poszczególnych regionalnych obszarów inteligentnej specjalizacji wspólnych agend badawczych, obejmujących priorytetowe przedsięwzięcia badawczo-rozwojowe istotne dla rozwoju firm zlokalizowanych w tych obszarach. 
Elementem dokumentu Regionalna Strategia Innowacji Województwa Lubelskiego do 2020 roku [2014] sa programy pilotażowe. Celem programu „Partnerstwa, sieci i klastry” jest wzmocnienie zdolności absorpcyjnej firm poprzez zainicjowanie partnerstw i rozwój współpracy sieciowej podmiotów, w tym przede wszystkim przedsiębiorstw $\mathrm{w}$ dziedzinach inteligentnych specjalizacji. W proces budowy partnerstw i tworzenia sieci kooperacyjnych zaangażowane zostaną nie tylko funkcjonujące i nowo powstające inicjatywy klastrowe, grupy producentów rolnych czy lokalne grupy działania, ale przede wszystkim kluczowe przedsiębiorstwa z różnych pokrewnych sektorów, zainteresowane współpracą ze swoimi kooperantami bądź jednostkami naukowo-badawczymi. Ważną rolę w rozwoju partnerstw lokalnych będa miały gminy i powiaty oraz podległe im jednostki organizacyjne, które będa musiały wykazać się odpowiednią otwartością i aktywnością w tym zakresie. Zakłada się, że w wyniku podjętych działań dojdzie do powstania nowych struktur współpracy (np. klastrowych), zostaną uruchomione nowe kanały komunikacji i wymiany wiedzy oraz opracowany zestaw instrumentów umożliwiających efektywne wsparcie partnerstw i współpracy sieciowej podmiotów działających w obszarach inteligentnych specjalizacji. Efektywnie działających klastrów, w tym o charakterze ponadregionalnym w 2020 r. ma być 35 (przy założeniu 23 w 2014). $\mathrm{Na}$ koniec $2012 \mathrm{r}$. formalnie zarejestrowanych było 18 inicjatyw klastrowych [Regionalna Strategia Innowacji..., 2014, s. 15, 32, 51].

Dokument Strategia rozpoju wojewódźtwa lubelskiego na lata 2014-2020 (z.perspektywa do roku 2030) [2013, s. 73] wskazuje jedynie na potrzebę zintegrowanych działań, w celu rozszerzenia aktywności w sektorze gospodarczym, stąd proponuje się jako kierunek interwencji władz, wspieranie procesów współpracy i sieciowania przedsiębiorstw z sektora MŚP.

\subsection{Założenia dla województwa warmińsko-mazurskiego}

Dla województwa warmińsko-mazurskiego niezwykle istotna jest jakość i charakter wspólpracy między instytucjami otoczenia biznesu, światem nauki, przedsiębiorcami i samorządem terytorialnym. W Strategii rozwoju społeczno-gospodarczego województwa warmińsko-mazurskiego do roku 2025 [2013] jako jeden z priorytetów strategicznych przyjęto nowoczesne sieci. Uznano, iż w globalnej gospodarce istotnym czynnikiem rozwoju regionów jest ich obecność w różnego rodzaju sieciach. Warunkuje to otwarte społeczeństwo (kolejny priorytet strategiczny województwa), czyli chęć kształcenia i podnoszenia kwalifikacji, podejmowania ryzyka i współpracy, a także budowanie zaufania [Strategia rožpoju społeczno-gospodarczego..., 2013, s. 7].

Wzrost konkurencyjności gospodarki (pierwszy cel strategiczny) ma być realizowany poprzez rozwój inteligentnych specjalizacji, któremu ma służyć współpraca jako jeden z kierunków działan. Powinien być realizowany przede wszystkim poprzez inicjowanie, tworzenie i współpracę instytucjonalną na poziomie lokalnym, międzyregionalnym i międzynarodowym ( $\mathrm{w}$ tym klastry, grupy producenckie, stowarzyszenia skupiające przedsiębiorców, współpraca na linii nauka - biznes, tworzenie centrów kompetencji inteligentnych specjalizacji). Nacisk położony 
będzie również na rozwój powiązań sieciowych na mikroekonomicznym szczeblu przedsiębiorstw prowadzących do wzrostu efektywności, konkurencyjności i powiększania rynków zbytu.

Cel strategiczny trzeci dotyczy wzrostu liczby i jakości powiązań sieciowych. Kluczowym podmiotem w realizacji tego celu będzie administracja publiczna. Osiagnięcie celów operacyjnych będzie wymagało wysokiej jakości funkcjonowania administracji, jej otwartości na współpracę oraz wysokiego zaangażowania w wykorzystywaniu różnych form współpracy na rzecz rozwoju regionu. To właśnie sieciowa wspólpraca powinna być ważnym narzędziem budowania relacji na różnych poziomach - formalnych i nieformalnych, branżowych i interdyscyplinarnych, dla osiagania efektów synergii. Kierunkiem działań w zakresie doskonalenia administracji ma być współpraca - administracja powinna rozwijać swoje funkcje jako „animatora” regionalnego i lokalnego. Konieczne będzie wsparcie administracji w zakresie kreowania aktywności społeczności lokalnych, budowania partnerstw (między samorządami, na linii samorzą - przedsiębiorcy, organizacje pozarządowe), włączania obywateli w proces współdecydowania o rozwoju, a także współpracy jednostek samorządu terytorialnego w celu dzielenia się wykonywaniem usług publicznych [Strategia rozwoju spoteczno-gospodarczego..., 2013, s. 46-53].

Region warmińsko-mazurski stawia za cel ciagła promocję współpracy wśród wszystkich uczestników regionalnego systemu innowacji, zwłaszcza przedsiębiorstw. Jest to jeden z celów operacyjnych, służących realizacji celu strategicznego - budowanie silnego kapitału społecznego i kultury innowacji [Regionalna Strategia Innowacyjności..., 2010]. Działalność instytucji tworzących regionalny system innowacji nie będzie w pełni efektywna bez współpracy, która przyczynia się do uzyskania większych korzyści niż w przypadku działania w pojedynkę. Współpraca pozwala na wymianę doświadczeń, uczenie się na błędach innych oraz inspirowanie się działalnościa partnera, którym może być zarówno przedsiębiorstwo, jak i jednostka samorządu, instytucja wsparcia czy też podmiot sektora badawczo-rozwojowego. Przedsiębiorstwa poprzez współpracę mogą uzyskać korzystniejsze ceny u dostawców, moga zaplanować wspólna, bardziej efektywną promocję swoich produktów, zamówić wspólnie usługę w jednostce badawczej czy pracować razem nad rozwiązaniem innowacyjnym [Regionalna Strategia Innowacyjności..., 2010, s. 23].

\subsection{Założenia dla województwa świętokrzyskiego}

Potrzeba wieloaspektowej współpracy widoczna jest w założeniach dokumentu Strategia Rozwoju Wojewódžtwa Świętokraysskiego do 2020 roku [2013] w odniesieniu do różnych celów strategicznych.

Cel drugi strategii zakłada koncentrację na kluczowych gałęziach i branżach dla rozwoju gospodarczego regionu. Jego realizacji służyć ma jeden z celów operacyjnych, dotyczący pakietyzacji i komercjalizacji produktu turystycznego - czyli rynkowej gry zespołowej. Wyzwaniem dla województwa jest umiejętne skonstruowanie produktu turystycznego wyróżniającego województwo świętokrzyskie (połączenie elementów kulturowych, uzdrowiskowych, przyrodniczych, historycznych, 
kulinarnych w jedną atrakcyjną całość). Pakietyzacja oferty turystycznej jest rozwiązaniem umożliwiającym pełniejsze wykorzystanie potencjału turystycznego i przyrodniczego regionu, wysokiego zróżnicowania wewnątrzregionalnego oraz wielowiekowego i bogate kultury materialnej i duchowej. Powinna ona opierać się na angażowaniu usługodawców rynku turystycznego w tworzeniu wspólnych inicjatyw, atrakcji, biletów [Strategia Rozivoju Wojewódz̨twa Swietokrayyskiego..., 2013, s. 35].

Zgodnie $\mathrm{z}$ zapisami $\mathrm{w}$ strategii trzeci cel strategiczny to koncentracja na budowie kapitału ludzkiego i bazy dla innowacyjnej gospodarki. Służyć ma temu usprawnienie i rozwój regionalnego systemu innowacji poprzez znoszenie barier w kooperacji między samorządem, uczelniami, jednostkami badawczymi, parkami technologicznymi i przedsiębiorstwami. Budowanie współpracy pomiędzy głównymi aktorami Regionalnego Systemu Innowacji stanowi warunek konieczny powstawania rozwiązań innowacyjnych i ich komercjalizacji. Samorząd województwa ma odgrywać kluczowa rolę jako inicjator współpracy oraz jej koordynator. Istotnym bodźcem powinno być tu wspólne wypracowanie inicjatyw, które moga zostać zakwalifikowane jako tzw. inteligentna specjalizacja. Dla realizacji trzeciego celu strategicznego służyć ma także cel operacyjny związany z tworzeniem sprzyjających warunków dla przedsiębiorczości, w tym przede wszystkim sektora MŚP, czyli dla podmiotów, które finalnie decyduja o innowacyjności. Istotna rola w tym zakresie przypada władzom samorządowym, które powinny wspierać powiązania sieciowe pomiędzy przedsiębiorcami, tworzenie nowych i rozwój istniejących klastrów jako źródeł zewnętrznych korzyści skali oraz promować wśród przedsiębiorców korzyści wynikające z powiązań kooperacyjnych [Strategia Roz̨woju Wojewódz̨twa Świetokrayyskiego..., 2013, s. 37-39].

Dla regionu kluczowy jest udział w tworzonych sieciach współpracy oraz wymiany doświadczeń pomiędzy regionami UE, m.in. dotyczących nauki, przedsiębiorczości, produktów turystycznych. Przygotowanie województwa do zwiększenia aktywności $\mathrm{w}$ tych obszarach wymaga intensyfikacji działań promocyjnych oraz rozwoju różnorodnych form współpracy z partnerami społecznymi (samorządami regionalnymi i lokalnymi, organizacjami międzynarodowymi, uczelniami, podmiotami gospodarczymi) [Strategia Rozwoju Województwa Świętokrzyskiego..., 2013].

Strategia rozwoju województwa wyznacza główne kierunki rozwoju województwa i wskazuje na istniejące ekonomiczne potencjały. Celem RIS3 jest dalsze rozwinięcie tych potencjałów poprzez wybranie „inteligentnych specjalizacji”, które pozwolą na zwiększenie efektywności wsparcia publicznego udzielanego dla rozwoju innowacji, związanych z nowymi technologiami, ale również z nowymi sposobami wykorzystania siły roboczej, organizacji procesu produkcji czy marketingu i w rezultacie przyspieszenie rozwoju gospodarczego. Zgodnie z założeniami dokumentu każda ze specjalizacji winna być wdrażana przez właściwa koncepcję rozwoju, przez lidera specjalizacji dysponującego kompetencjami w zakresie animowania współpracy podmiotowej, wymiany informacji, animowania transferu wiedzy i technologii z sektora $\mathrm{B}+\mathrm{R}$ do firm działających w specjalizacjach, promocji innowacji itp. [Strategia badań i innowacyjności wojewódz̨twa świetokersyskiego..., 2014]. 


\section{Podsumowanie}

Władze regionalne Polski Wschodniej w opracowanych strategicznych dokumentach programowych odnoszą się do problemu współpracy sieciowej. W poszczególnych województwach ma to miejsce w różnych częściach dokumentów, m.in. we wnioskach z przeprowadzonej diagnozy, wizji rozwoju, celach strategicznych, celach szczegółowych dla realizacji wizji, kierunkach działań dla realizacji celów i dziedzin strategicznych czy efektach działań. W trzech województwach: warmińsko-mazurskim, świętokrzyskim i lubelskim, podkreśla się szczególną rolę władz samorządowych we wspieraniu współpracy klastrowej. Wszystkie regiony dostrzegają klastry jako instrument konkurencyjności, innowacji i wzrostu w regionie oraz instrument wspierający rozwój inteligentnych specjalizacji. Niestety tylko w nielicznych dokumentach wskazane są konkretne instrumenty wsparcia dla ich rozwoju. Ma to miejsce w dokumencie Regionalna Strategia Innowacji Województwa Lubelskiego do 2020 roku [2014], w którym wskazuje się na sposoby pobudzenia i rozwoju wspó1pracy sieciowej. Spośród 5 województw tylko jedno województwo (tj. województwo podkarpackie) posiada odrębny dokument poświęcony klastrom oraz prezentuje politykę klastrową w sposób kompleksowy. W dokumentach strategicznych pozostałych województw brakuje konkretnych rozwiązań prowadzenia polityki opartej o klastry. Skromność bezpośrednich nawiazań do problematyki klastrów w dokumentach strategicznych może być pochodną ich ograniczonej jeszcze obecności w życiu społeczności lokalnych [Lisowska, Rubisz, 2011].

W tabeli 2 zawarto przewidziane do uruchomienia instrumenty wsparcia klastrów, wynikające z założeń dokumentów planistycznych województw Polski Wschodniej. Wskazane instrumenty mają charakter wybiórczy. Dominują wśród nich działania na rzecz zaangażowania, kształtowania wyspecjalizowanych zasobów pracy, marketingu regionu. Ponadto, analiza praktycznych działan sprzyjających rozwojowi klastrów na przykładzie województwa podlaskiego, przeprowadzona przez M. Klimczuk-Kochańską [2012, s. 171], pozwala stwierdzić, że działania te nie składaja się na spójną politykę rozwoju klastrów, mają charakter incydentalny i podejmowane sa przede wszystkim przez przedsiębiorstwa $i$ instytucje otoczenia biznesu (zauważono zbyt bierną rolę władz).

Należy dążyć do tego, aby przygotowane nowe bądź uaktualniane przez władze samorządowe dokumenty programowe uwzględniały konkretne instrumenty wsparcia dla klastrów z każdej z grup działań proponowanych przez S.A. Rosenfelda (por. tabela 1). Tylko zaplanowane wcześniej działania będa miały szansę na praktyczną ich realizację. Przykładowe działania, jakie powinny być stosowane przez administrację samorządową na rzecz klastrów poza wyżej wyszczególnionymi, to: wpływanie na rozwój szkolnictwa i zmiany w systemie edukacyjnym, zwiększenie masy krytycznej podmiotów gospodarczych, wspieranie rozwoju instytucji naukowych i badawczych, odpowiednie inwestycje w infrastrukturę, tworzenie w urzędach komórek organizacyjnych do spraw klastrów. Na konieczność opracowania strategii rozwoju różnych klastrów, które pozwoliłyby na sprecyzowanie celów do osiagnięcia oraz ustalenie roli różnych podmiotów w realizacji działań na rzecz 
rozwoju klastrów wskazuje M. Klimczuk-Kochańska [2012, s. 171]. Szanse na rozwój regionów w oparciu o inteligentne specjalizacje będzie też uzależnione od wsparcia istniejących i tworzących się klastrów przez dofinansowanie działań koordynatorów, w tym prowadzonych przez nich inicjatyw klastrowych. Zapewni to funkcjonowanie instytucji odgrywających kluczową rolę dla rozwoju współpracy, interakcji i przepływów wiedzy w ramach skupisk działalności gospodarczej, a tym samym podnoszenia ich konkurencyjności i innowacyjności [Ropega, 2016, s. 102].

\section{Instrumenty wsparcia klastrów przewidziane w dokumentach strategicznych województw Polski Wschodniej}

\begin{tabular}{|l|l|}
\hline Województwo & \multicolumn{1}{|c|}{ Instrumenty wsparcia klastrów } \\
\hline Podkarpackie & $\begin{array}{l}\text { tworzenie jednostek wspierających powstawanie klastrów, wsparcie finan- } \\
\text { sowe dla klastrów działających (m.in. preferencje podatkowe), szkolenie } \\
\text { i doradztwo, promocja klastrów i ich działalności (imprezy targowe, } \\
\text { kampanie promujące, promocja ponadregionalna i międzynarodowa), } \\
\text { regionalna platforma wymiany wiedzy i doświadczeń miedzy klastrami, } \\
\text { platforma informacyjna o klastrach }\end{array}$ \\
\hline Podlaskie & $\begin{array}{l}\text { kształtowanie niezbędnych kompetencji do współpracy, promowanie } \\
\text { sieciowania przedsiębiorstw }\end{array}$ \\
\hline Lubelskie & $\begin{array}{l}\text { instrumenty dedykowane profesjonalizacji kadr i organizacji zarządzają- } \\
\text { cych klastrami, instrumenty pozwalające wypracować agendy badawcze } \\
\text { dla poszczególnych obszarów IS, Program pilotażowy Partnerstwa, sieci, } \\
\text { klastry - zaangażowanie istniejących inicjatyw w tworzenie nowych part- } \\
\text { nerstw, kluczowych przedsiębiorstw z sektorów pokrewnych, aktywizacja } \\
\text { gmin i powiatów i podległych im jednostek organizacyjnych w rozwój } \\
\text { partnerstw, nowe kanały komunikacji i wymiany wiedzy }\end{array}$ \\
\hline $\begin{array}{l}\text { Warmińsko- } \\
\text {-mazurskie }\end{array}$ & $\begin{array}{l}\text { kształcenie, podnoszenie kwalifikacji i budowanie zaufania dla otwartego } \\
\text { społeczeństwa warunkującego nowoczesne sieci; tworzenie centrów } \\
\text { kompetencji inteligentnych specjalizacji; rozwój funkcji administracji jako } \\
\text { animatora współpracy; promocja współpracy }\end{array}$ \\
\hline Świętokrzyskie & $\begin{array}{l}\text { znoszenie barier w kooperacji; rola samorządu jako inicjatora i } \\
\text { koordynatora współpracy; intensyfikacja działań promocyjnych } \\
\text { współpracy }\end{array}$ \\
\hline
\end{tabular}

Źródło: opracowanie własne na podstawie: [Regionalna Strategia Innowacji..., 2014; Regionalna Strategia Innowacyjności..., 2010; Strategia badań i innowacyjności województwa świetokryyskiego..., 2014; Plan rozwoju przedsiębiorczości..., 2016; Woźniak i in., 2015; Strategia rozwoju spoteczno-gospodarcそego..., 2013; Strategia rozwoju wojewódz̨twa - Podkarpackie..., 2013; Strategia rozpoju województwa lubelskiego..., 2013; Strategia Rozwoju Województwa Podlaskiego..., 2013; Strategia Rozwoju Województwa Świetokrayskiego..., 2013].

Reasumując, rozwój konkretnych klastrów, szczególnie w regionach o niskim potencjale gospodarczym, powinien odbywać się w oparciu o świadomie działania polityki regionalnej. Impulsy ze strony polityki regionalnej mogą okazać się szczególnie ważne w inicjowaniu i przyspieszaniu kształtowania się klastrów 
w sytuacji braku silnych liderów gospodarczych czy rozwiniętych sieci innowacyjnych przedsiębiorstw [Soliński, 2012, s. 38].

\section{Literatura}

Boekholt P., Thuriaux B., 1999, Overview of Cluster Policies in International Perspective, A Report for the Dutch Ministry of Economic Affairs, Final Report.

Brodzicki T., Szultka S., 2002, Koncepcja klastrón a konkurencyjność przedsiębiorstw, „Organizacja i kierowanie”, nr 4(10), s. 45-60.

Brodzicki T., Szultka S., Tamowicz P., 2004, Polityka wspierania klastrów. Najlepsze praktyki. Rekomendacje dla Polski, Niebieskie Księgi 2004. Rekomendacje, nr 11, Instytut Badań nad Gospodarką Rynkowa, Gdańsk.

Bucka M., 2017, Wsparcie rozwoju klastrón w Polsce w perspektywie finansowej 2014-2020, „Prace Naukowe Uniwersytetu Ekonomicznego we Wrocławiu”, nr 466, s. 63 70, DOI: $10.15611 /$ pn.2017.466.06.

Buczyńska G., Frączek D., Kryjom P., 2016, Raport z inwentaryzacji klastrów w Polsce 2015, PARP, Warszawa.

Del Castillo J., Barroeta B., Paton, J., 2012, Converting Smart Specialisation into a Regional Strategy, INFYDE Workig Paper, vol. 2/1, pp. 103-110.

Dzierżanowski M., 2006, Raport otwarcia nt. polskiej polityki klastrowej, PARP, Warszawa.

European Trend Chart on Innovation, Thematic Report - Cluster Policies, 2003, European Commission.

Figiel A., Węgrzynek B., 2013, Polityka rozwoju oparta o klastry (CLUSTER-BASED POLICY - CBP), https://klastrypolskie.pl/news [data wejścia: 22.10.2018].

Foray D., Goddard J., Beldarrain X.G., Landabaso M., McCann P., Morgan K., Nauwelaers C., Ortega-Argilés R., 2012, Guide to Research and Innovation Strategies for Smart Specialisations (RIS3), Publications Office of the European Union, Luxembourg, European, http://ec.europa.eu/regional_policy/sources/ docgener/presenta/smart_specialisation/smart_ris3_2012.pdf [data wejścia: 15.06. 2017].

Gurba K., 2012, Rola uczelni w klastrach uysokich technologii, „Zarządzanie i Finanse”, r. 10, nr 1, cz. 2, s. 79-90.

Innovation Clusters in Europe. A Statistical Analysis and Overview of Current Policy Support, DG Enterprise and Industry Report, 2007, European Commission.

Kaźmierski J., 2012, Roz̧wój $i$ zarz̨adzanie strukturami klastronymi w regionie, Uniwersytet Łódzki, Łódź.

Ketels Ch., 2009, Clusters, Cluster Policy, and Swedish Competitiveness in the Global Economy, Expert report no. 30 to Sweden's Globalisation Council, The Globalisation Council, Stockholm, February.

Ketels Ch., 2013, Clusters and Public Policy: Recent Learnings, Current Challenges, Lisbon.

Kierunki i polityka rozwoju klastrón w Polsce, 2009, Ministerstwo Gospodarki, Departament Rozwoju Gospodarki, Warszawa. 
Klimczuk-Kochańska, 2012, Politykea rozwoju klastrów w wojewódẓtwie podlaskim - dotychczasowe doświadczenia i kierunki rozwoju, „Optimum. Studia Ekonomiczne”, nr 4(58), s. $155-173$.

Komunikat Komisji. Europa 2020. Strategia na rzecz inteligentnego i zrównoważonego rozwoju sprayjajacego właczeniu, 2010, Komisja Europejska, Bruksela, COM (2010)2020, wersja ostateczna.

Kraska E., 2012, Wpływ władz samorzqdowych na tworzenie i funk.jonowanie klastrów na praykktadzie gmin wojewódz̨twa świętokrzyskiego, "Zarządzanie i Finanse”, nr 1, cz. 2 s. 91-98.

Kraska E., 2013, Klastry w polityce regionalnej województwa śmiętokrayyskiego, „Studia i Materiały. Miscellanea Oeconomicae", nr 1, s. 39-47.

Lisowska A., Rubisz S., 2011, Sektor instytucji publicznych a rozwój klastrów w województwie opolskim, Wydawnictwo Instytut Śląski Sp. z o.o, t. 6, Opole.

Maj M., Rychlicki P., 2011, Kierunki rozwoju Województwa Podkarpackiego w oparciu o klastry, Openfield Research \& Communications, Opole.

Naussbaum B., 2013, Creative Intelligence. Harnessing the Power to Create, Connect and Inspire, HarperBusiness, New York.

Olko S., 2015, Instrumenty wsparcia klastrów kreatywnych w Polsce i Europie, „Barometr Regionalny", t. 13, nr 4, s. 113-118.

Pilarska Cz., 2010, Polityka oparta na klastrach w wybranych krajach UE, „Zeszyty Naukowe. Polskie Towarzystwo Ekonomiczne", nr 8, s. 89-118.

Plan rozwoju przedsiębiorczości w oparciu o inteligentne specjalizacje województwa podlaskiego na lata 2015-2020+ (RIS3), 2016, Zarząd Województwa Podlaskiego, załącznik do uchwały nr 120/1431/2016 Zarządu Województwa Podlaskiego z dnia 1 marca 2016.

Plawgo B., 2010, Kierunki rozwoju polityki wspierania klastrów w Polsce, www.pi.gov.pl [data wejścia: 22.10.2018].

Plawgo B., 2014, Benchmarking klastrów w Polsce - edycja 2014. Raport z badania, Polska Agencja Rozwoju przedsiębiorczości, Warszawa.

Porter M.E., 2001, Porter o konkurencji, PWE, Warszawa.

Regionalna Strategia Innowacji Województwa Lubelskiego do 2020 roku, 2014, Sejmik Województwa Lubelskiego, załącznik do uchwały Sejmiku Województwa Lubelskiego nr XLIX/794/2014 z dnia 31 października 2014.

Regionalna Strategia Innowayjności Województwa Warminsko-Mazurskiego do roku 2020, 2010, Sejmik Województwa Warmińsko-Mazurskiego, załącznik do uchwały nr XLIII/832/10 Sejmiku Województwa Warmińsko-Mazurskiego z dnia 28 września 2010.

Rola sektora kultury i przemystów kreatywnych w rozwoju miast i aglomeracii, 2010, Klasik A. (red.), Prace Naukowe UE w Katowicach, Wydawnictwo Uniwersytetu Ekonomicznego.

Romanowska E., Firgolska A., Hrudeń J., 2014, Strategia inteligentnej specjalizacji w kontekście wybranych regionów Polski, „Przedsiębiorstwo we współczesnej gospodarce - teoria i praktyka", nr 2, s. 55-78. 
Ropega J., 2016, Znaczenie wdrożenia inteligentnych specjalizacji dla rozwoju sektora MŚP, „Management Sciences”, nr 3(28), s. 93-104, DOI: 10.15611/noz.2016.3.07.

Rosenfeld S.A., 2002, Creating Smart System. A Guide to Cluster Strategies in Less Favored Regions. A Report, European Union-Regional Innovation Strategies, Regional Technology Strategies, Carrboro, North Carolina.

Sanetra-Półgrabi S., 2011, Instrumenty wspierania rozwoju regionalnego i ich znaczenie, „Przegląd Naukowo-Metodyczny. Edukacja dla Bezpieczeństwa”, nr 3, s. 101-110.

Skawińska E., Zalewski R., 2009, Klastry biznesowe w rožoju konkurencyjności i innowacyjności regionów. Świat-Europa-Polska, PWE, Warszawa.

Soliński T., 2012, Znaczenie klastrón w transferze innowacji i rozwoju turystyki, [w:] Ochrona środowiska w aspekcie zrównoważonego rozwoju spoteczno-gospodarczego Pogórza Dynowskiego, Krupa J., Soliński T. (red.), Związek Gmin Turystycznych Pogórza Dynowskiego, Dynów.

Strategia badań i innowacyjności wojewódz̨twa świetokersyskiego. Od absorpcii do rezultatón - jak pobudric potencjat wojewódz̧twa świetokryyskiego 2014-2020+, 2014, Sejmik Województwa Świętokrzyskiego, załącznik do uchwały nr XL/706/14 Sejmiku Województwa Świętokrzyskiego z 24 lutego 2014.

Strategia rozwoju spoteczno-gospodarczego województwa warmińsko-mazurskiego do roku 2025, 2013, Sejmik Województwa Warmińsko-Mazurskiego, załącznik do uchwały nr XXVIII/553/13 Sejmiku Województwa Lubelskiego z dnia 25 czerwca 2013.

Strategia rozpoju województwa - Podkarpackie 2020, 2013, Samorząd Województwa Podkarpackiego, 2013, Rzeszów.

Strategia rožoju wojewódz̧twa lubelskiego na lata 2014-2020 (z perspektywa do roku 2030), 2013, Sejmik Województwa Lubelskiego, uchwała nr XXXIV/559/2013 Sejmiku Województwa Lubelskiego z dnia 24 czerwca 2013.

Strategia Rozwoju Województwa Podlaskiego do 2020 roku, 2013, Zarząd Województwa Podlaskiego, załącznik do uchwały nr 150/2157/2013 Zarządu Województwa Podlaskiego z 19 marca 2013.

Strategia Rožwoju Województwa Świętokrayskiego do roku 2020, 2013, Sejmik Województwa Świętokrzyskiego, załącznik do uchwały nr XXXIII/589/13 Sejmiku Województwa Świętokrzyskiego z dnia 16 lipca 2013.

Szymoniuk B., 2014, Polityka klastrowa - dobrodziejstwo czyy przęeleństwo dla polskich klastrów?, „Prace Naukowe Uniwersytetu Ekonomicznego we Wrocławiu”, nr 369, t. 2, s. 212-221, DOI: 10.15611/pn.2014.369.219.

Wierżyński W., 2012, Rzeszonska Dolina Klastrón, www.pi.gov.pl [data wejścia: 20.05. 2017].

Woźniak L., Sobkowiak A., Dziedzic S., Kąkol W., Kud K., Woźniak M., Wyrwa D., 2015, Regionalna Strategia Innowacii Województwa Podkarpackiego na lata 2014-2020 na ręecz. Inteligentnej Specjalizacji, Rzeszów. 